... Fedyukov, Saldayeva, Chernova, Chernov: Cone Morphology as a Diagnostic Attribute...

\title{
Cone Morphology as a Diagnostic Attribute of Resonant Properties of Standing Spruce Wood
}

\section{Morfologija češera kao dijagnostički atribut rezonantnih svojstava drva smreke}

\author{
Original scientific paper • Izvorni znanstveni rad \\ Received - prispjelo: 15. 5. 2017. \\ Accepted - prihvaćeno: 1. 12. 2017. \\ UDK: $630 * 812.12 ; 674.032 .477 .22$ \\ doi:10.5552/drind.2017.1731
}

\begin{abstract}
The paper presents the results of dendroacoustic research and statistical and correlation analysis. The insights of heuristic identification based on biotechnology law are also given with the aim of defining the relationship of wood resonant properties with the form of seed scales of spruce growing in the Kama-Volga region of Russia.
\end{abstract}

Key words: sonorous spruce, cone biomorphology, wood macrostructure, density, sound velocity, acoustic constant, dendroacoustic indices identification

SAŽETAK - U radu su prikazani rezultati dendroakustičkog istraživanja te statističke i korelacijske analize. Autori također daju uvid u heurističku identifikaciju utemeljenu na primjeni biotehničkog zakona radi definiranja odnosa rezonantnih svojstava drva i oblika ljuske smrekova sjemena u ruskoj regiji Kama-Volga.

Ključne riječi: akustična smreka, biomorfologija češera, makrostruktura drva, gustoća drva, brzina zvuka, akustična konstanta, identifikacija dendroakustičkih indikacija

\section{INTRODUCTION}

\section{UVOD}

It is well-known that the ways to diagnose and select wood for manufacturing both musical instruments and acoustic panels for theatres and conservatories (Fedyukov et al., 2011) can be conventionally classified into direct and indirect.

Direct methods are based on determining dendroacoustic indices with the help of ultrasonic and other instruments for measuring sound velocity in wood, its frequency-amplitude characteristics, and a number of other physical and mechanical properties (Bucur, 2006; Fedyukov and Makaryeva, 1992). Based on the results obtained, the main criterion of 'musicality' of the material, i.e. its acoustic constant of sound propagation $K$, is defined. In many countries, $K \geq 12$ $\mathrm{m}^{4} / \mathrm{kg} \cdot \mathrm{cm}$ is accepted for resonant wood.

Direct methods involve some technical difficulties in conducting studies in the forest and are still used primarily in the laboratory environment.

\footnotetext{
${ }^{1}$ Author is professor and head of the Sounding Timber Qualimetry Scientific and Production Laboratory of the Volga State University of Technology, Yoshkar-Ola, Russia. ${ }^{2}$ Authors are associate professor, post graduate student and associate professor at Volga State University of Technology, Chair of Standardization, Certification and Merchandizing, Yoshkar-Ola, Russia.

${ }^{1}$ Autor je profesor i voditelj Znanstvenoistraživačkoga i proizvodnog laboratorija za akustiku drva, Državno tehnološko sveučilište Volga, Yoshkar-Ola, Rusija. ${ }^{2}$ Autori su izvanredni profesor, doktorand i izvanredni profesor Državnoga tehnološkog sveučilišta Volga, Odjel za standardizaciju, certifikaciju te tehnologiju i poznavanje roba, Yoshkar-Ola, Rusija.
} 
Indirect methods are based on visual tree assessment with respect to its species and biomorphological features, such as branching type and crown shape, bark color and structure, stem habit (Bagayev and Alexandrov, 1976; Gavris, 1938; Pchelin, 1961; Redulescu, 1969).

It is impossible to find reliable data on the way these attributes were used by Stradivari and other masters of the Old Italian school in the selection of wood for manufacturing unique musical instruments. However, it is wrong to exclude this, as later and modern ways of visually estimating the resonance quality of standing tree wood applied the attributes mentioned above.

\section{Visual appearance and conditions of a tree}

According to modern masters, a spruce tree selected for manufacturing musical instruments should meet the following requirements:

- be absolutely vertical;

- have symmetric, narrow and spiry crown;

- have a cylindrical trunk and branchless zone no less than 5-6 meters;

- not contain other visible defects and damages.

Thicker trunks are in demand: if the diameter at breath height is less than $35 \mathrm{~cm}$, i.e. at the age of less than 100-120 years, the use of such a tree as a source of resonant material is considered counterproductive.

A Rumanian scientist, V. Grapini (1967), gives more detailed data for resonant spruce:

- the crown is in the form of a column, almost symmetric, gradually decreases from the basis to the top at an angle of $30-40^{\circ}$ and is formed by thin branches oriented mainly downwards;

- the branches from the third part of the middle and the bottom of a crown are attached to the trunk at an angle of $30-40^{\circ}$; large branches are arranged in clusters; - the second order branches are rather rare, thin, long, hanging down, ash-gray-green;

- the third order branches are also rare, thin, but light green.

A lot of individual masters also consider descending branches to be an attribute of a resonant spruce. The fact that it 'is not warped' is especially valued. It is determined by attentive inspection of a tree with regard to clusters arrangement, bark cracks, etc., which requires considerable experience.

\section{Bark structure and color}

These morphological attributes of spruce are often used by masters selecting the material for manufacturing musical instruments from the root and round assortments. However, there is no general opinion about any characteristic attribute that can be undoubtedly acceptable as diagnostic.

This is probably related to strong variability of the above attributes, which also correlate with biological and ecological features of individual trees (Onegin and Kuznetsova, 2012; Pat. № 2130611 RF, 1999; Pchelin, 1961; Pravdin, 1975).

Absence of a uniform method to give the diagnostics of acoustic properties of standing tree wood is caused by the elements of subjectivity in conclusions based on the results of observations by different au- thors, especially, in different soil, climate and geographical environment.

Selector Yablokov (1962) recommends to select spruce trees with smooth bark forms (low land, in his opinion) as resonant; this coincides with the opinion of Gavris (1938). Bagayev and Alexandrov (1967), who believe that smooth-barked spruce-trees with narrow crown of both Norway and Siberian species have the best resonance.

Sankin (1972) conducted a thorough research on determining the relations between the variability of macrostructure, anatomical structure of wood, physical, mechanical and acoustic properties depending on spruce tree bark appearance (rhytidoma) in the environment of the Vologda Region of Russia. Having studied the trees of two groups (with platy and scaly bark), he came to a conclusion that spruce with scaly bark is preferable due to greater genetic plasticity. Meanwhile, the relationship of late wood percentage and annual ring width with wood density, dynamic modulus of elasticity and acoustical constant is equally strongly expressed in both groups.

Basing on such biomorphological preconditions, some scientists consider that there is a certain phylogenetic biotype of resonant spruce (Grapini, 1967; Pravdin, 1975).

Further to the above review of scientific literature, it can be concluded that hereditary genetic factors prevail in the formation of wood quality. They manifest themselves in quite a sustained way through external biomorphological features of cones, including their size and seed scale forms (Bakshayeva, 1966; Danilov, 1943; Mamayev and Nekrasov, 1968; Onegin and Kuznetsova, 2012; Pchelin, 1961; Redulescu, 1969; Yablokov, 1962).

It is necessary to bear in mind that each master chooses, at his discretion, the characteristic attributes of wood 'musicality' as a criterion for visual estimation of the resonant raw material. The criteria used by individual masters or representatives of different schools are different as a rule, with rare exceptions.

In this connection, uniform diagnostic attributes should be established for mathematical modeling and development of an objective way of selection of standing spruce trees with resonant properties in certain nature-climate environment of its growth.

\section{MATERIALS AND METHODS}

\section{MATERIJALI I METODE}

Searching an objective biomorphological attribute, we chose the seed scale form from the middle part of the cone.

Danilov's (1943) and Bakshayeva’s (1966) methods are taken as a basis for drawing up a matrix of initial data to differentiate the trees inside a population with respect to seed scale form, which results from their characteristic features.

Danilov's method is most detailed. It is based on the analysis of four attributes: 
... Fedyukov, Saldayeva, Chernova, Chernov: Cone Morphology as a Diagnostic Attribute...

Table 1 Tree classification

Tablica 1. Klasifikacija stabala

\begin{tabular}{|l|c|c|}
\hline Attributes / Atributi & Symbolic representation / Simbolički prikaz \\
\hline 1. Scale edge angle / rubni kut ljuske & Mean & $\mathrm{I}$ \\
up to $45^{\circ}$ & $30^{\circ}$ & $\mathrm{II}$ \\
$45^{\circ}-75^{\circ}$ & $60^{\circ}$ & $\mathrm{III}$ \\
$75^{\circ}-105^{\circ}$ & $90^{\circ}$ & $\mathrm{IV}$ \\
$105^{\circ}-135^{\circ}$ & $120^{\circ}$ & $\mathrm{V}$ \\
$135^{\circ}$ and more & $150^{\circ}$ & $\mathrm{O}$ \\
\hline 2. Angle form of a scale edge / oblik kuta na rubu ljuske & Obtuse / tup & $\mathrm{A} / \mathrm{R}$ \\
\hline 3. Nature of generatrix / izgled izvodnice & Acute, round /oštar, okrugao & $\mathrm{SM}$ \\
& Smooth-margined / glatko omeđena & $\mathrm{S}$ \\
\hline 4. Outside edge type / izgled vanjskog ruba & Serrated / nazubljena & $\mathrm{SN}$ \\
& Sinuous / vijugav & $\mathrm{E}$ \\
\hline
\end{tabular}

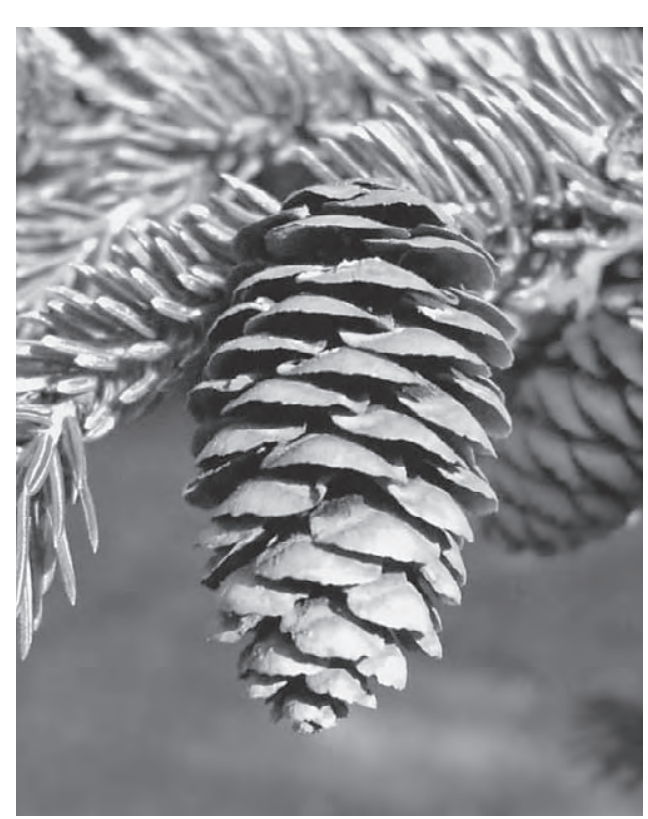

a)

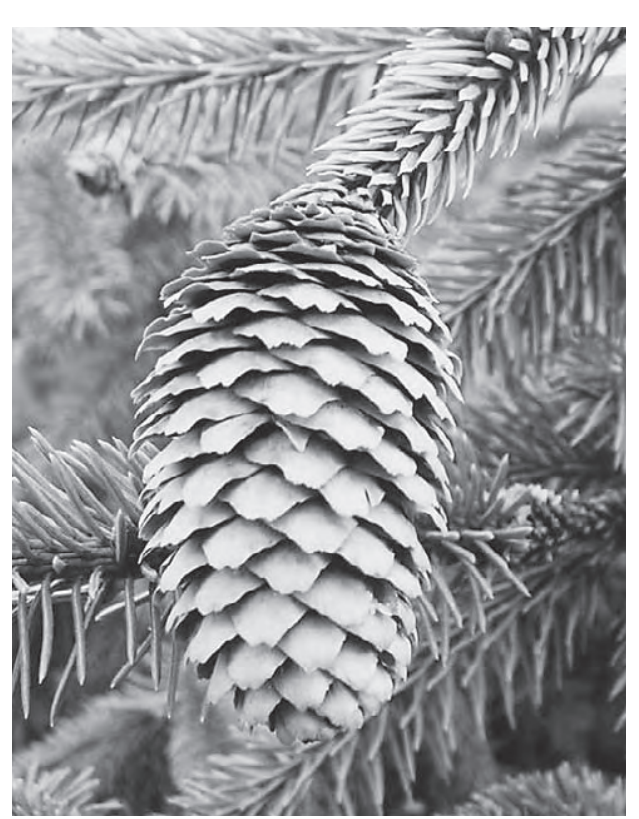

b)

Figure 1 Spruce seed scale form: a) Siberian spruce; b) Norway spruce

Slika 1. Oblik ljuske sjemena smreke: a) sibirska smreka; b) norveška smreka

a) degree of scale edge tapering - the main attribute (5 classes);

b) angle form of a scale edge (obtuse, acute, round);

c) nature of generatrix (smooth-margined or serrated);

d) outside edge type (straight, sinuous, even).

The method of tree classification according to the above attributes is presented as a whole in Tab. 1.

As an example, Siberian spruce is characterized by rounded smooth-margined seed scales of cones, while the Norway spruce is characterized by lengthened, a little bit pointed hackly ones (Fig. 1).

However, hybrid forms of spruce can be met more often, and they can be classified in detail using the method given.

Using Bakshayeva's method of classification, it is comparatively simple and easy to translate the data into mathematical language. It is based on defining the factor through the ratio of height $H$ of the seed scale top part to its width in the widest part $l$ (Fig. 2).

All the variety of seed scales is reduced to three groups depending on the size of the factors obtained: groups I, II and III at $H / l=1.32$ (Norway spruce); = 0.09 (Siberian spruce) and $=1.0$ (hybrid form).
Based on cone classification according to Bakshayeva's method (1966), it was possible to establish unequivocally that 39 model trees selected were Siberian Spruce, and Danilov's classification made it pos-

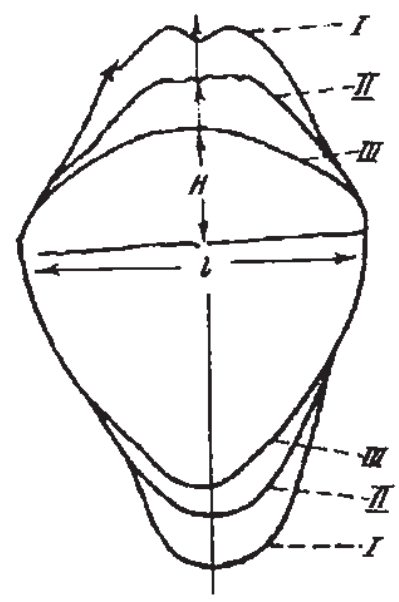

Figure 2 Scheme of spruce seed scale form variability according to Bakshayev (1966)

Slika 2. Shema varijabiliteta oblika ljuske smrekova sjemena prema Bakshayevu (1966.) 


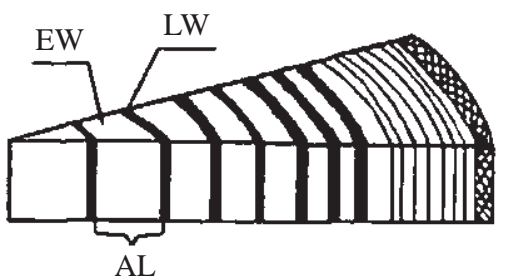

a)

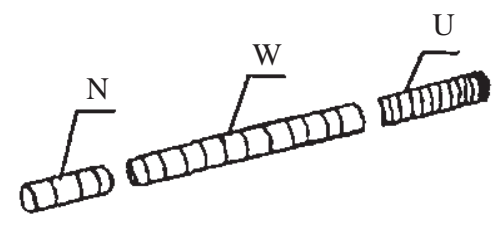

b)

Figure 3 General view of wood macrostructure according to the trunk zone: a - elements of wood macrostructure (EW - early wood; LW - late wood; AL - annual ring); b - scheme of core division according to zones ( $\mathrm{N}$ - near-core zone; $\mathrm{W}$ - working zone; U - undercork zone)

Slika 3. Prikaz makrostrukture drva u zoni debla: a) elementi makrostrukture drva (EW - rano drvo, LW - kasno drvo, AL - god); b) shema osnovne podjele prema zonama (N - zona blizu srca, $\mathrm{W}$ - radna zona, $\mathrm{U}$ - zona ispod pluta)

sible to classify 10 types of combination of seed scale attributes distributed as follows:

\begin{tabular}{ll}
\multicolumn{1}{c}{$\begin{array}{c}\text { Types of frequent } \\
\text { occurrence, pcs. }\end{array}$} & \multicolumn{1}{c}{$\begin{array}{c}\text { Types of rare } \\
\text { occurrence, pcs. }\end{array}$} \\
1. III $(\mathrm{O}+\mathrm{S}+\mathrm{E})-8$ & 1. IV $(\mathrm{O}+\mathrm{S}+\mathrm{E})-4$ \\
2. IV $(\mathrm{A} / \mathrm{R}+\mathrm{SM}+\mathrm{E})-7$ & 2. III $(\mathrm{A} / \mathrm{R}+\mathrm{S}+\mathrm{E})-1$ \\
3. III $(\mathrm{O}+\mathrm{S}+\mathrm{SN})-6$ & 3. III $(\mathrm{O}+\mathrm{SM}+\mathrm{E})-1$ \\
4. III $(\mathrm{A} / \mathrm{R}+\mathrm{SM}+\mathrm{E})-5$ & 4. II $(\mathrm{O}+\mathrm{S}+\mathrm{SN})-3$ \\
& 5. IV $(\mathrm{A} / \mathrm{R}+\mathrm{S}+\mathrm{E})-3$ \\
& 6. V $(\mathrm{A} / \mathrm{R}+\mathrm{SM}+\mathrm{E})-1$
\end{tabular}

According to this classification, hybrid form trees having cone seed scales with obvious attributes of Siberian spruce are of frequent occurrence.

This was confirmed by the research site. The fact of the matter is that model trees were taken from ripe spruce groves of the Kirov Region in a taiga zone. In this region, European spruce is hardly ever met in its pure form, but rather in the hybrid form (Ovechkin, 1982).

Cross-section radial cores, $4.0 \mathrm{~mm}$ in diameter, selected with an increment borer at breath height from 16 model trees, after being felled, were the material for the research into dendroacoustic parameters. Simultaneously, diameters of trunks at relative heights of $0.2 \mathrm{H}, 0.5 \mathrm{H}$ and $0.7 \mathrm{H}$, as well as tree crown parameters (extension, first alive knot fastening height, etc.) were defined.
The method of determining the resonance of wood in standing trees against the cores has been introduced abroad (Bucur, 2006) and in Russia (Fedyukov and Makaryeva, 1992) rather recently.

As a rule, wood structure is different along the length of a radial core and, accordingly, wood physical and mechanical parameters are also different in medullary parts and in sapwood. This distinction is obvious even with a naked eye, first of all, judging from wood macrostructure: narrow annual rings are in trunk peripheral zone and wide ones are close to juvenile central zone (Fig. 3, a).

Rather homogeneous wood between undercork and near-core zones is usually taken for deck manufacturing. In view of this, the study was focused on the part of the trunk along the radius, conditionally denoted on cores as a 'working' zone (Fig. 3, b).

Basic physical and dendroacoustic properties of wood - humidity, density, macrostructure, and ultrasound velocity - were defined in laboratory environment. Recalculation of the results obtained against standard humidity of wood, $W=12 \%$, was made. The complex research is presented in Fig. 4.

The macrostructure of wood was studied with electronic dendrometer, which operates on the basis of

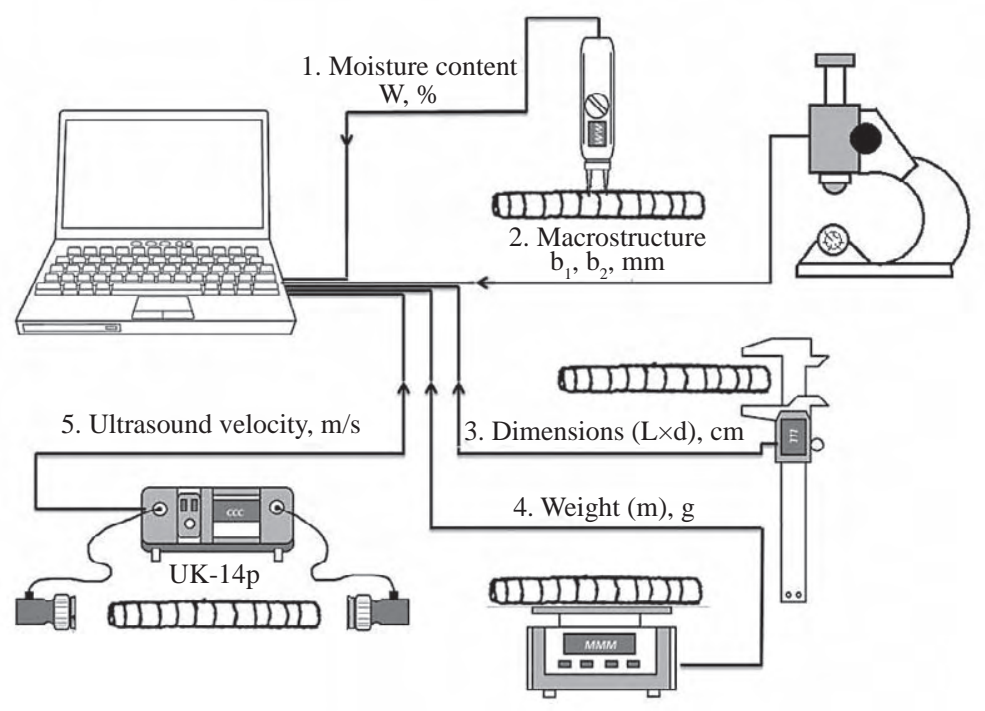

Figure 4 Principle diagram of experimental measurements Slika 4. Shematski prikaz eksperimentalnih mjerenja 
assessment of early $\left(\mathrm{b}_{1}\right)$ and late $\left(\mathrm{b}_{2}\right)$ wood zone width in annual rings according to their microhardness (Pat. № 2130611 RF., 1999).

Sound velocity in wood $(C)$ was assessed with a pulse ultrasonic method by fixing the time $(\tau)$ of elastic longitudinal wave propagation along the sample (l):

$$
C=l / \tau
$$

It should be noted that the device was equipped with a $60 \mathrm{kHz}$ piezoelectric transducer, which is optimal for wood study.

Based on sound velocity in the material, $C$, and its density, it is possible to assess Young's dynamic modulus, $E$, on the basis of the following ratio:

$$
C=\sqrt{\frac{E_{\mathrm{dyn}}}{\rho}}, \text { then } E_{\mathrm{dyn}}=C^{2} \cdot \rho
$$

It is known that, today, acoustic constant of sound propagation $(K)$, suggested by the Academician N.N. Andreyev, is accepted as the basic criterion of 'musicality' of a given material in many countries:

$$
K=\sqrt{\frac{E}{\rho^{3}}}
$$

Threshold value is $\mathrm{K} \geq 12.0 \mathrm{~m}^{4} / \mathrm{kg} \cdot \mathrm{cm}$ for resonant wood in a longitudinal direction along fibers, and under cross-section radial measurements $\mathrm{K} \geq 3.5 \mathrm{~m}^{4}$ / $\mathrm{kg} \cdot \mathrm{cm}$ (Ugolev, 2001).

Small transformations and joint solution of equations 2 and 3 allow to define the size of acoustical constant $K$ through $C$ and $\rho$ :

$$
\left\{\begin{array}{l}
K=\sqrt{\frac{E}{\rho^{3}}} \\
C=\sqrt{\frac{E}{\rho}}
\end{array}=>K=\frac{C}{\rho}\right.
$$

Thus, the physical essence of resonant wood represents a combination of incongruous properties, i.e., high parameters of rigidity, sound velocity and low density.

Processing of statistical data for determining the relationship of the cones (seed scales) form with physical, mechanical and acoustic properties of wood was supplemented with heuristic identification of the results obtained with a general model (Mazurkin, 1989):

$$
y=a_{1} \exp \left(-a_{2} i_{\mathrm{f}}\right)+a_{2} i_{\mathrm{f}}^{a_{4}} \exp \left(-a_{5} i_{\mathrm{f}}\right)+a_{6} i_{\mathrm{f}}^{a_{7}}
$$

where $a_{1} \ldots a_{7}$ are regression coefficients (model parameters); $i_{f}$ is cone seed scale form code (individual rank); $y$ is theoretical value of physical, mechanical and acoustic properties of wood parameters.

According to this technique, coding of morphological attributes of cone seed scales for the specified trees is developed to perform further calculations on the basis of Danilov's classification. Values of attributes are classified by transition from the Norway spruce to Siberian spruce.

Attribute values were classified in accordance with the transition from Norway spruce to Siberian spruce.

Rank scale $1 . . .40(5 \times 2 \times 2 \times 2)$ is theoretically possible. The present (specific) scale contains 10 positions, as many combinations of attribute values are absent in the growth environment researched (Tab. 2).

Integer scales $i_{f}$ and $I_{f}$ are four-factorial in the given coding, scale $I_{f}=1 . .40$ taking into account specific morphological variety of spruce features in different regions of the country.

Using PC and Eureka mathematical environment, the results of corresponding parameters identification were obtained. Parameters adequacy values according to model 5 are shown in Tab. 4.

Maximal residual $\varepsilon_{\max }$ was calculated according to the formula:

$$
\varepsilon_{\max }=\max \left\{\hat{y}_{\mathrm{i}}-\mathrm{y}_{\mathrm{i}}\right\}
$$

\begin{tabular}{|c|c|c|c|c|c|}
\hline \multirow{2}{*}{$\begin{array}{l}\text { Specific rank } \\
\text { Specifični rang }\end{array}$} & \multirow[b]{2}{*}{ 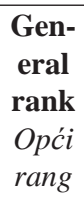 } & \multicolumn{4}{|c|}{ Scale form parameters / Vrijednosti parametara oblika ljuske } \\
\hline & & \begin{tabular}{|c|} 
Angle \\
sharpness class \\
Klasa oštrine \\
kuta
\end{tabular} & $\begin{array}{l}\text { Apex type } \\
\text { Oblik vrha }\end{array}$ & $\begin{array}{l}\text { Generatrix nature } \\
\text { Izgled izvodnice }\end{array}$ & $\begin{array}{l}\text { Outside edge type } \\
\text { Izgled vanjskog ruba }\end{array}$ \\
\hline 1 & 9 & II & obtuse / tup & serrated / nazubljena & sinuous / vijugav \\
\hline 2 & 17 & III & « & « & « \\
\hline 3 & 18 & III & « & « & even / ravan \\
\hline 4 & 20 & III & « & smooth-margin / glatko omeđena & « \\
\hline 5 & 22 & III & acute / oštar & serrated / nazubljena & « \\
\hline 6 & 24 & III & « & smooth-margin / glatko omeđena & « \\
\hline 7 & 26 & IV & obtuse / tup & serrated / nazubljena & « \\
\hline 8 & 30 & IV & acute / oštar & « & « \\
\hline 9 & 32 & IV & « & smooth-margin / glatko omeđena & « \\
\hline 10 & 40 & $\mathrm{~V}$ & « & « & « \\
\hline
\end{tabular}

where $\hat{y}_{i}, y_{i}$ are experimental and theoretical parameter values.

Table 2 Position rank scale according to spruce cone seed scales

Tablica 2. Rangiranje češera smreke prema obliku ljuski sjemenki

Note: Angle sharpness class value is $45-75^{\circ}$ for class II; 75 - $105^{\circ}$ for class III; 105 - $135^{\circ}$ for class IV; more than $135^{\circ}$ for class V./ Napomena: Veličina kuta prema klasi oštrine jest 45 - $75^{\circ}$ za klasu II; 75 - $105^{\circ}$ za klasu III; 105 - $135^{\circ}$ za klasu IV; više od $135^{\circ}$ za klasu V. 
Maximal relative error $\Delta_{\max }$ was calculated using the formula:

$$
\Delta_{\max }=100 \frac{\left|\varepsilon_{\max }\right|}{\hat{y}\left(\varepsilon_{\max }\right)}
$$

\section{RESULTS AND DISCUSSION 3. REZULTATI I RASPRAVA}

Values of correlation coefficients $(R)$ and correlation ratio $(\eta)$ of dendroacoustic parameters and seed scales form, according to Bakshayeva (1966), are presented in Tab. 3.

According to the above table, there are certain relationships between a specific biomorphological attribute and the basic dendroacoustic parameters, all correlation coefficients being positive because the relationships are direct. However, the reliability of these relationships is less than $95 \%$; e.g. the relationship of correlation coefficients with seed scales form for $K$ and $b$ is only about $90 \%$ reliable; as for $E$ and $v$, the reliability is much lower, and for $\rho$ and $\delta$ it is close to zero.

The correlation ratio $\eta$ against all parameters, except for $b$, is higher than the correlation coefficient $R$. Hence, a nonlinear relationship would be more appropriate than a linear one.

Table 3 Values of correlation coefficient $(R)$ and correlation ratio $(\eta)$ of dendroacoustic parameters and seed scale forms Tablica 3. Vrijednosti koeficijenta korelacije $(R)$ i omjera korelacije ( $\eta$ ) dendroakustičkih parametara i oblika ljuske sjemena

\begin{tabular}{|l|c|c|}
\hline Parameters / Parametri & $\boldsymbol{R}$ & $\boldsymbol{\eta}$ \\
\hline Annual ring width b / Širina goda, $b$ & 0.599 & 0.593 \\
\hline $\begin{array}{l}\text { Late wood proportion } \delta \\
\text { Udjel kasnog drva, } \delta\end{array}$ & 0.076 & 0.405 \\
\hline Density $\rho$ / Gustoća, $\rho$ & 0.044 & 0.389 \\
\hline Ultrasound velocity v / Ultrazvučna brzina, v & 0.460 & 0.593 \\
\hline $\begin{array}{l}\text { Modulus of elasticity E } \\
\text { Modul elastičnosti, } E\end{array}$ & 0.408 & 0.482 \\
\hline $\begin{array}{l}\text { Acoustical constant } K \\
\text { Akustična konstanta } K\end{array}$ & 0.565 & 0.767 \\
\hline
\end{tabular}

In practice, when selecting a resonant raw material (standing tree), it should be noted that the correlation between acoustic constant coefficient and seed scales form (0.767) appeared to be maximum with high level of reliability (0.99\%).

Parameters adequacy values according to model 5 are shown in Table 4.

The results presented in Tab. 4 confirm that model 5 describes the relationship of scale form with parameters of physical, mechanical and acoustic properties of spruce wood, in this case with $\delta, \rho, v$ and $K$, with rather small relative error $\Delta_{\max }<10 \%$ for practical purposes.

Basically, model 5 is characterized by three kinds of biotechnology law (Mazurkin, 1989). The first component describes the process of parameters $\delta, \rho$ and $v$ value recession in transition from Norway spruce to Siberian spruce. The width of annual rings depends on habitat conditions rather than on species diversity.

The second component of the model is characterized by stressful change of parameters $\delta, b$ and $v$. Stressful influence of hybrid species strongly affects the width of annual rings and practically does not change the density. This fact does not mean the absence of relationship between wood density and width of annual rings; it mainly emphasizes the possibility of purposeful forming of resonant wood with specific macrostructure.

The third part of the model describes allometric growth of scale form influence.

Fig. 5 presents the graphs of parameters change depending on an integer scale $i_{f}$. Parameters $\delta$ and $b$ change under the wave law (Fig. 5, a). Values $\rho$ and $v$ (Fig. 5, b) are minimal at various codes $\left(i_{f}=7\right.$ and $i_{f}=$ 3 ). Such unequal extremes of the graphs require accounting for the complex parameter $K$, which is defined as the $v / \rho$ ratio. Since $i_{f}$ grows from 1 to $10, K$ value increases almost rectilinearly (Fig. 5, c).

Graph $K=f\left(i_{f}\right)$ shows that Siberian spruce has better resonant properties than Norway spruce. Sound velocity in a radial direction at breath height increases likewise.

The analysis of these graphs disproves the opinion of some researchers about the absence of heredi-

Table 4 Parameters adequacy values according to model 5

Tablica 4. Adekvatnost parametara prema modelu 5.

\begin{tabular}{|c|c|c|c|c|c|c|}
\hline $\begin{array}{l}\text { Parameters of models } \\
\text { Parametri modela }\end{array}$ & b, $\mathbf{m m}$ & $\delta, \%$ & $\rho, \mathrm{kg} / \mathrm{m}^{3}$ & $v, \mathbf{m} / \mathbf{s}$ & $K, \mathrm{~m}^{4} /(\mathrm{kg} \cdot \mathrm{cm})$ & $E, \mathrm{~kg} /\left(\mathrm{m} \cdot \mathrm{s}^{2}\right)$ \\
\hline$a_{1}$ & 0 & 35.1 & 472.75 & 1640.3 & 3.0600 & 12.839 \\
\hline$a_{2}$ & 0 & 0.2605 & 0.01952 & 0.11238 & 0.01976 & 0.2509 \\
\hline$a_{3}$ & 8.284 & 0.003841 & 0 & 1.7693 & 0 & 0 \\
\hline$a_{4}$ & 4.3490 & 15.718 & 0 & 6.2744 & 0 & 0 \\
\hline$a_{5}$ & 2.7136 & 3.4173 & 0 & 1.0045 & 0 & 0 \\
\hline$a_{6}$ & 0.4641 & 0.2698 & 0.009907 & 3.0075 & 0.05205 & 0.4639 \\
\hline$a_{7}$ & 0.5469 & 2.0025 & 5.2846 & 2.4915 & 1.2503 & 1.3910 \\
\hline$\varepsilon_{\max }$ & 0.203 & 1.365 & 22.61 & 100.6 & 0.243 & 1.94 \\
\hline$\Delta_{\max }, \%$ & 12.3 & 5.72 & 5.23 & 7.10 & 7.04 & 21.0 \\
\hline
\end{tabular}


... Fedyukov, Saldayeva, Chernova, Chernov: Cone Morphology as a Diagnostic Attribute...

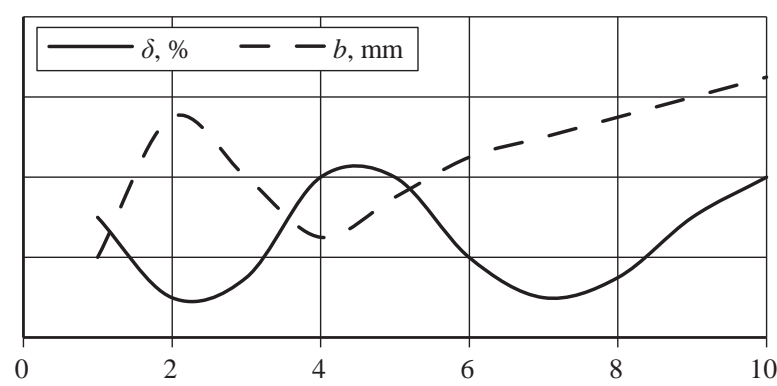

a)

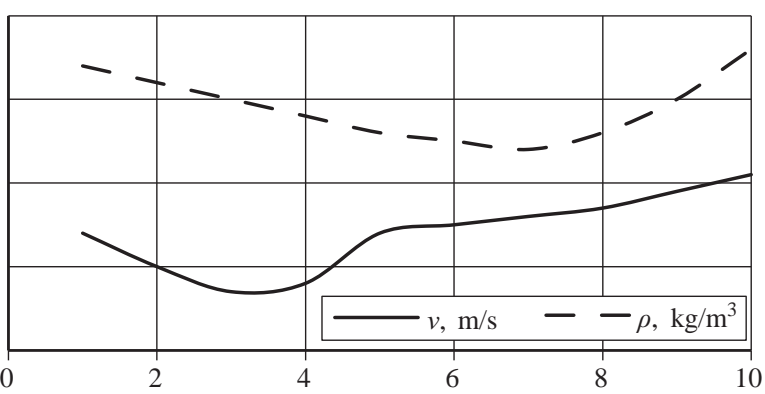

b)

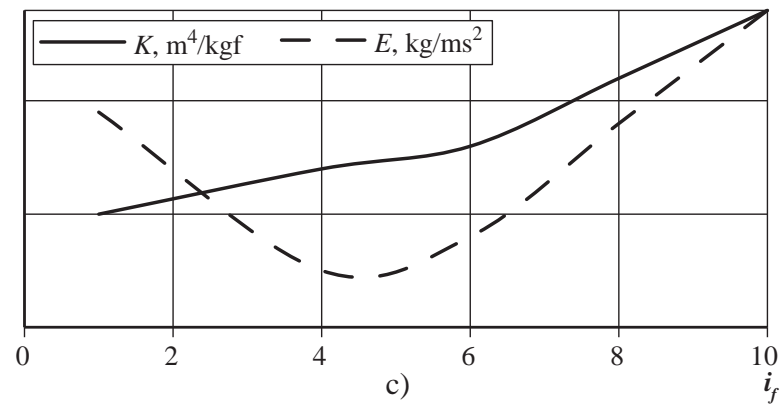

Figure 5 Parameters change depending on integer scale $i_{f}$ Slika 5. Promjena parametara ovisno o cijeloj vrijednosti $i_{f}$ tary-genetic factor role in the formation of wood resonant properties and, accordingly, their transfer to subsequent generations of spruce trees, saying that ' $a$ resonant spruce is usual spruce wood that happened to grow in a certain specific environment' (Onegin and Kuznetsova, 2012).

It is important to note that the probability of the occurrence of the best resonant properties in spruce is observed at $v>1,400 \mathrm{~m} / \mathrm{s}$. Further modeling of $v$ change depending on other factors, $b$ and $\delta$ in particular, made it possible to derive the equation:

$$
\begin{aligned}
\vartheta= & \left(1,165.67+8,352.49 b \frac{\delta}{100}\right) \exp (-1.4626) . \\
& \cdot\left(b \frac{\delta}{100}\right)^{0.3381}
\end{aligned}
$$

Model (4) describes the law of aperiodic motion with fast attenuation under the influence of late wood as a damper of sound velocity in radial direction. Thus $\varepsilon_{\max }=17,278 \mathrm{~m} / \mathrm{s} ; \Delta_{\max }=11.3 \%$.

The constant component of sound velocity $(1,376.25 \mathrm{~m} / \mathrm{s})$ and influence of annual ring average width are taken into account under the biotechnology law in the model

$$
\begin{gathered}
\vartheta=11,376.25+8,355.32 b^{26.1478} \exp (-10.0818 \cdot b)(9) \\
\text { where } \varepsilon_{\text {max }}=149.92 \mathrm{~m} / \mathrm{s} ; \Delta_{\max }=9.82 \% .
\end{gathered}
$$

The graph in Fig. 6.a clearly illustrates a significant increase of sound velocity under $b>1 \mathrm{~mm}$.

According to the complex law of aperiodic motion, the model for defining wood density (Fig. 6, b) is obtained as follows:

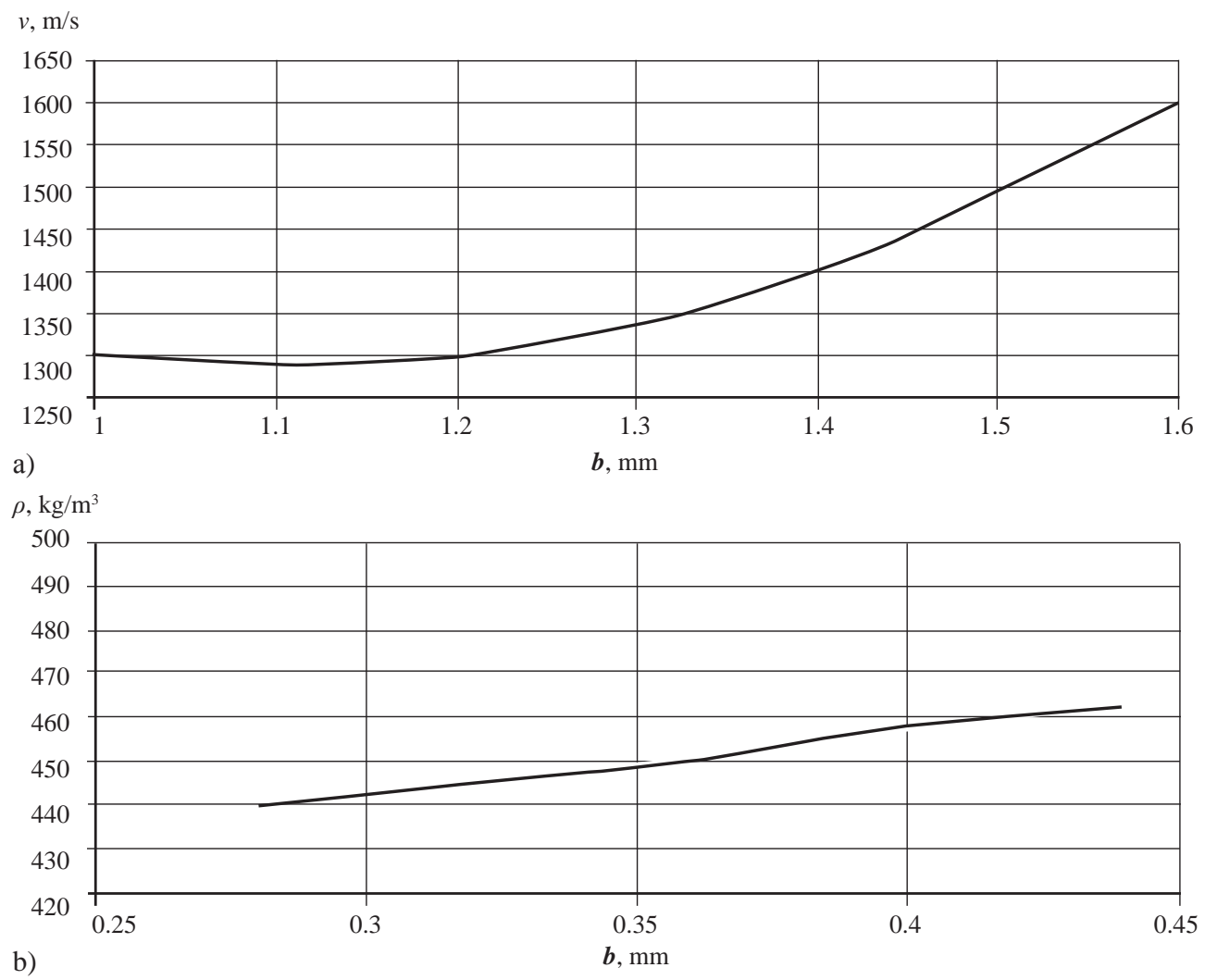

Figure 6 Dynamics of sound velocity (a) and density (b) depending on wood annual ring width

Slika 6. Dinamika brzine zvuka (a) i gustoće (b) ovisno o širini goda 


$$
\begin{aligned}
\rho= & \left(450+8359.05 \cdot b \frac{\delta}{100}\right) \exp \left(-2.6014 \cdot b \frac{\delta}{100}^{0.3130}\right)- \\
& \left.-0.09229 \cdot b^{1.3332}\right)
\end{aligned}
$$

where $\varepsilon_{\max }=33.90 \mathrm{~m} / \mathrm{s} ; \Delta_{\max }=8.01 \%$.

A more simple aperiodic model for density is described by the equation:

$$
\rho=\left(450+8359.05 \cdot b_{d}\right) \exp \left(-2.9520 \cdot b_{d}\right)^{0.3643}(11)
$$

where $\varepsilon_{\max }=38.21 \mathrm{~m} / \mathrm{s} ; \Delta_{\max }=8.01 \%$.

Models 9 and 11 are adequate at the $95 \%$ level of reliability.

\section{CONCLUSIONS}

4. ZAKLJUČAK

In conclusion, the main results of the research can be summarized as follows:

1. Seed scales form of spruce is a rather significant biomorphological attribute describing genetic and, to a certain extent, phytocenotic predisposition of a tree to forming resonant wood with good acoustic properties.

2. Hybrid forms have lower acoustic parameters of wood than pure forms of Norway or Siberian spruce, resonant properties improving in the process of transition from Norway spruce to Siberian spruce.

3. Close correlation between the basic physical, mechanical and acoustic parameters of wood remain even against the background of its genetic and phytocenotic (ecological) variability.

4. Spruce seed scales form can be a characteristic attribute for non-destructive diagnostics of standing tree resonant properties.

\section{REFERENCES}

\section{LITERATURA}

1. Bagayev, S. N.; Alexandrov, V. O., 1976: Selection of resonant spruce against phenotype. Inf. sheet 125-76, Kostroma CSTI. Kostroma, Issue 38, 3 p.

2. Bakshayeva, V. I., 1966: Variability and a shape diversity of spruce in Karelia. Extended abstract of Cand. Sci. (Agric.) Dissertation. Petrozavodsk. 20 p.

3. Bucur, V., 2006: Acoustics of Wood. Springer Verlag, Berlin - Heidelberg, 393 p.

4. Danilov, D. N., 1943: Variability of Picea excelsa seed scales. Botanical Journal, 5: 57-63.

5. Fedyukov, V. I.; Saldayeva, E. Yu., 2011: Resonant spruce for the Bolshoi Theatre reconstruction. Forest Journal, 2: 13-24.
6. Fedyukov, V. I.; Makaryeva, T. A., 1992: The diametrical rod as object for nondestructive method resilient-viscous characteristics definition of standing and sawn resonant wood. All-Division 5 conference „Forest product“. Conference pleniere division 5 „Produits forestiers“. Proceedings actes working session de travaill. Volume 1. Nancy, France, August / Aott 23-28, pp. 344-345.

7. Gavris, V. P., 1938: Diversity of forms of coniferous breeds and practical use of valuable forms of the pine and the spruce. Forest Industry, 1 (7): 78-88.

8. Grapini, V., 1967: Molidulde rezonantr. Revista Prdurilor, A. - 82, - 7, - P. 334-344.

9. Mazurkin, P. M., 1989: Heuristic regression analysis of natural management phenomena and processes. MarPI., Yoshkar-Ola, 316 p.

10. Mamayev, M. S.; Nekrasov, M. S., 1968: Variability of spruce cones in the forests of the Middle Urals. Proc. of the Institute of Ecology of Animals and Plants, 2: 46-58.

11. Onegin, V. I.; Kuznetsova, E. G., 2012: Research into the structure of coniferous wood and its influence on physical, mechanical and acoustic properties of lignin. Izvestya of St-Petersburg Forest Engineering Academy, No. 199, pp. 192-203.

12. Ovechkin, S. M., 1982: Introgressive hybridization of Norway and Siberian Spruce from Kirov region and Udmurt ASSR. Forest Science, 5: 12-16.

13. Pat. № 2130611 RF., 1999: Method for and device for diagnosing wood resonant properties. V. I. Fedyukov, L. N. Veselov, V. L. Veselov. - RU 97109185; appl. 28. 5. 1997.; publ. 20. 5. 1999.; Bul. of invent., No. 4.

14. Pchelin, V. I., 1961: Silvicultural features and physical and mechanical properties of wood of red-coned and greenconed spruce in the environment of Mari ASSR. Extended abstract of Cand. Sci. (Agric.) Dissertation, L., 16 p.

15. Pravdin, L. F., 1975: Norway and Siberian Spruce in the USSR. M.: Nauka, 187 p.

16. Redulescu, A., 1969: Jn legrturr cu molidus de rezonantr. Revista Prdurilor, 84 (3): 218-221.

17. Sankin, N. A., 1972: Variability of resonant properties of Norway Spruce wood against the background of variation of anatomic and morphological attributes inside the population. Transactions / MFEI, 43: 57-65.

18. Ugolev, B. N., 2001: Wood science with basic concepts of timber merchandizing. - M: MGUL, $340 \mathrm{p}$.

19. Yablokov, A. S., 1962: Woody species selection. M.: Sel'khozizdat, $367 \mathrm{p}$.

\section{Coressponding address:}

\section{Prof. VLADIMIR FEDYUKOV, Ph.D.}

Volga State University of Technology

Lenin Sq., b. 3

Yoshkar-Ola, the Republic of Mari El

424000, RUSSIA FEDERATION

e-mail: fiv48@mail.ru 